\title{
The effect of the interaction of dietary protein and calcium on the growth and maintenance of the bones of young, adult and aged rats
}

\author{
By N. R. H. EL-MARAGHI, B. S. PLAT'T AND R. J. C. STEWART \\ Human Nutrition Research Unit, Nutrition Building, National Institute for \\ Medical Research, The Ridgeway, Mill Hill, London, $N W 7$
}

(Received 26 February 1965-Accepted 19 July 1965)

Bone rarefaction or osteoporosis is one of the most prevalent, painful and disabling diseases of late middle or old age, and there is evidence that there are two main forms for which the terms matrix- and mineral-osteoporosis have been suggested (Stewart, 1965). Matrix-osteoporosis is due to a reduced deposition of bone and has been produced in animals by starvation (Jackson, 1925) and protein-calorie deficiency (Fontaine, Mandel \& Gries, I950; Frandsen, Nelson, Sulon, Becks \& Evans, I954; Platt \& Stewart, 1962). Mineral-osteoporosis, on the other hand, is usually associated with the ingestion of diets of high or adequate protein value but of low mineral (primarily calcium) content; deposition of bone matrix is normal but, through the intervention of vitamin $\mathrm{D}$ and the parathyroids, there is an enhanced destruction of older bone so that mineral is released to supplement the inadequate dietary supply.

In many of the animal experiments purporting to demonstrate the effect of $\mathrm{Ca}$ deprivation, inanition and therefore protein-calorie deficiency (see Platt, Miller \& Payne, I96I) also occurred. A similar complication probably occurs in human subjects and would explain the observation of Nordin ( 1960 ) that in many of his osteoporotic patients with low intakes and retentions of $\mathrm{Ca}$ the intakes of protein were also low.

In view of this dual aetiology it would be expected that the condition of some patients would improve when $\mathrm{Ca}$ is added to their diets (Urist, I960; Nordin, I96I, 1962), and of others with protein therapy (Albright, Bartter, Dempsey, Forbes, Henneman \& Reifenstein, 1953). Neither treatment leads to marked radiographic evidence of improvement, and an endocrine imbalance due to a relative excess of corticosteroids has been suggested as a further complication (Albright, 1943, 1947; Reifenstein, I957). Women, especially after the menopause, are thought to be particularly susceptible to osteoporosis, but Urist (1960) and Caldwell (1962) found that in subjects over 50 years of age the condition was equally prevalent in men, although often remaining asymptomatic.

A reduced retention of $\mathrm{Ca}$ is certainly associated with bone rarefaction, but some of the abnormalities of bone found in human patients, and even the reduced retention of $\mathrm{Ca}$, may be linked with protein-calorie deficiency.

The present report is an attempt to evaluate the relative importance of the effect 
of dietary deficiencies of protein and $\mathrm{Ca}$ on the bones of rats, allowance being made for the differing protein requirements of growing and adult animals. The appetite of animals given diets of low protein value is often impaired and some allowance for this has been made by including rats given a high-protein diet in amounts equal to those eaten by the rats given the low-protein diets, i.e. pair-fed controls.

Preliminary reports (El-Maraghi \& Stewart, 1963, 1964; El-Maraghi, I964) have indicated that osteoporosis can be produced in rats by deficiencies of protein or $\mathrm{Ca}$ or both.

\section{EXPERIMENTAL}

\section{Animals and diets}

Rats of a black and white hooded colony which had been maintained on the MRC cube diet no 4I B (Bruce \& Parkes, 1947) were used for all the experiments. The young were removed from the dams at 2I days of age and, when not required for immediate test (Expts 2 and 3 ), were given the cube diet. When receiving the experimental diets the animals were individually housed in wire-mesh cages, given distilled water to drink and weighed at weekly intervals.

A semi-synthetic diet was designed containing maize starch, casein (25\%), arachis oil, salts and vitamins with a proportion of cellulose (solka floc obtained from Johnsen, Jorgensen \& Wettre, Ltd, London, $\mathrm{EC}_{4}$ ) to provide roughage (Table I). The protein value of the diet expressed as net dietary protein calories $\%(\mathrm{NDpCal} \%$ ) was 10.2 (Platt et al. 196I), which could be decreased by replacing $(\mathrm{w} / \mathrm{w})$ casein with starch until, with only $2 \%$ of casein, the protein value was reduced to NDpCal $\%=\mathrm{I} \cdot 6$ (Table $\mathrm{I}$ ).

The salt mixture described by Jones \& Foster (1942) was modified by replacing $(\mathrm{w} / \mathrm{w})$ the $\mathrm{CaCO}_{3}$ with maize starch and then supplying the requisite amounts of $\mathrm{Ca}$ as a mixture of $10 \% \mathrm{CaCO}_{3}$ in maize starch (Table $\mathrm{r}$ ). The $\mathrm{Ca}$ concentration of the diets was varied between $0.1 \mathrm{I}$ and $0.44 \%$.

In addition to the prepared diet, each animal was given $0.2 \mathrm{ml} /$ week of arachis oil containing 400 i.u. retinol, 20 i.u. ergocalciferol, $0.2 \mathrm{mg}$ menaphthone and $0.7 \mathrm{mg}$ mixed tocopherols.

Expt 1. Four male rats were maintained from the $3^{\text {rd }}$ to the I I th week of age on each of the diets $A$ to $M$ (Table $I$ ) and four female rats on each of diets $A, C, G$ and J. Pair-fed controls were included for each concentration of dietary $\mathrm{Ca}$.

Expt 2. Four male and four female rats were maintained from the 28th until the $4^{8 \text { th }}$ week of age on diets D, F, N and O. Pair-fed controls were included for each concentration of dietary $\mathrm{Ca}$. Three additional groups (see p. 499), each of four male and five female rats, were also given diet $\mathrm{O}$ (low-protein, low-Ca) for 20 weeks and then for a further ro weeks either the low-protein, high-Ca diet $(\mathrm{N})$, the high-protein, low-Ca diet (F), or the high-protein, high-Ca diet (D).

Expt 3. Four female rats aged $2-2 \frac{1}{2}$ years which had received diets of good protein value throughout life were maintained on each of diets $\mathrm{A}, \mathrm{C}, \mathrm{N}$ and $\mathrm{O}$; after 12 weeks two animals of each group were killed, and all the remaining animals were then given $\operatorname{diet} \mathrm{A}$ (high-protein, high-Ca) for a further period of 7 weeks. 


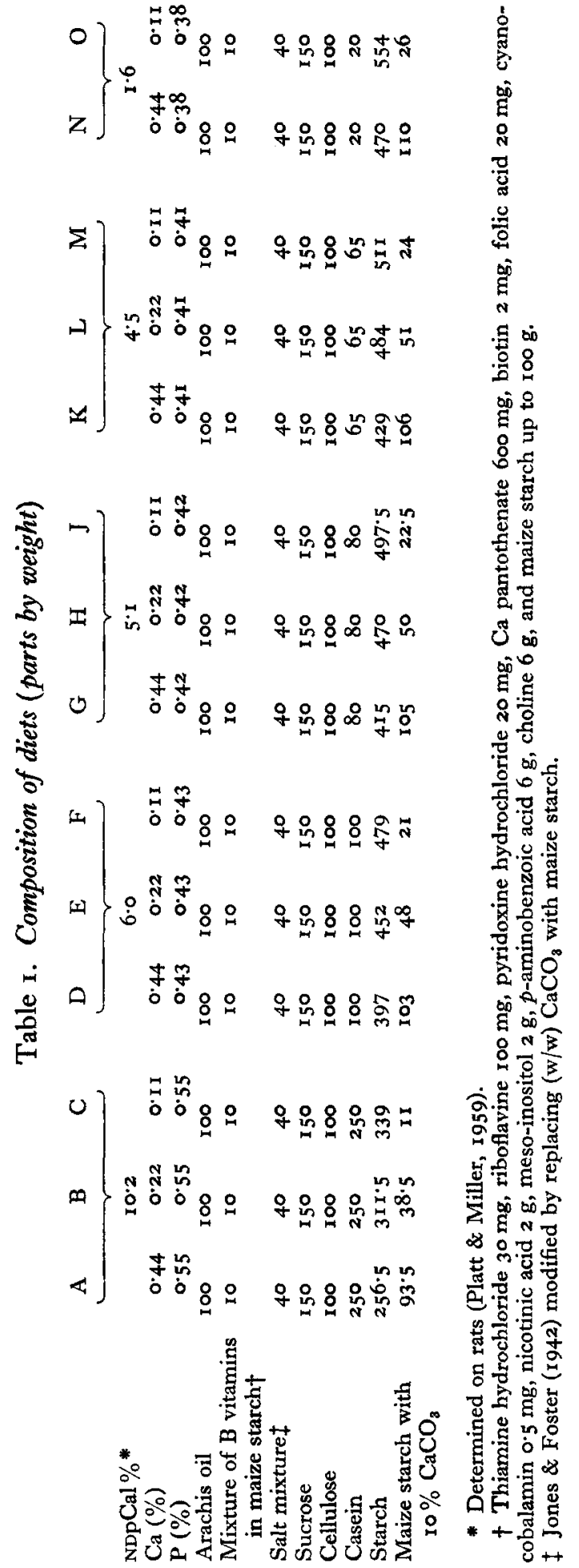




\section{Procedure}

At the end of the experiments the animals were killed with chloroform. Blood was removed from the heart and allowed to clot; the serum was used for determining the concentrations of $\mathrm{Ca}$ (Gran, 1960), inorganic phosphorus (Fiske \& Subbarow, I925) and protein (by the Kjeldahl technique).

Radiographs were taken on non-screen film (Ilfex; Ilford Ltd) with a Solus Eureka tube, $1.8 \mathrm{~mm}$ focus and a tube-to-film distance of 36 in to reduce errors due to parallax. Exposures were for $0.6 \mathrm{~s}$ at $23 \mathrm{kV}$ and $28 \mathrm{~mA}$. An aluminium step wedge was included in every exposure to facilitate comparisons between different films. On the few occasions when radiographs of the left forepaw were taken during life no anaesthetic was used.

The distal part of the left femur together with the proximal part of the tibia were prepared for histological examination as described by Platt \& Stewart (I962).

The right femurs were used for the determination of the $A: R$ ratio where $A$ is the weight of the ash of the bone (incinerated at $700^{\circ}$ ) and $\mathrm{R}$ that of the dry, fat-free bone minus the ash (Chick \& Roscoe, r926; Chick, Korenchevsky \& Roscoe, I926). This ratio was determined separately for the shaft and ends of the long bones so that values for the water, fat, ash and matrix of the shaft, ends or whole bone were also available.

The $A: R$ ratio and the total amounts of ash are measures of the quality and amount of mineralized matrix, but neither takes account of the distribution of the calcified tissue within the bone. The fresh volumes of the right femurs and and cervical vertebras were calculated from the weight of water they displaced and their ash content, expressed as $\mathrm{mg} / \mathrm{cm}^{3}$ of whole bone, was used to supplement the other measures of bone quality.

\section{RESULTS}

\section{Weight and food intakes}

\section{Expt I. Young rats}

Except for some greying of the hair and mild alopecia in the animals given the low-protein, high-Ca diet, all the animals remained in good condition and increased in body-weight, although at very different rates, throughout the experiment. The differences in the rates of weight increase brought about by alterations in the protein value of the diet were greater when the diet contained $0.44 \% \mathrm{Ca}$ than when it contained $0.11 \%$ (Fig. I).

The variations in food consumption between animals receiving diets of different protein value were small when the diets contained only 0 I I $\% \mathrm{Ca}$, but were larger when the diets contained 0.22 or $0.44 \%$ (Table 2 ). The rate of growth was roughly proportional to the intake of net dietary protein calories (NDpCal) per $\mathrm{kg}$ of metabolic size (body-weight ${ }^{0.73}$ ) and, as found by other workers, the protein efficiency ratio (PER) fell as the protein content of the diet was raised. More surprising was the alteration in PER brought about by differences in the concentration of $\mathrm{Ca}$ in the diet. When the protein value of the diet was high, decreasing the Ca from 0.44 to $0.11 \%$ 
led to a reduction in the PER, when the protein values were low to an increase; at the intermediate value $(\mathrm{NDpCal} \%=6 \cdot 0)$ there was, as in the weight gains, little effect (Table 2).

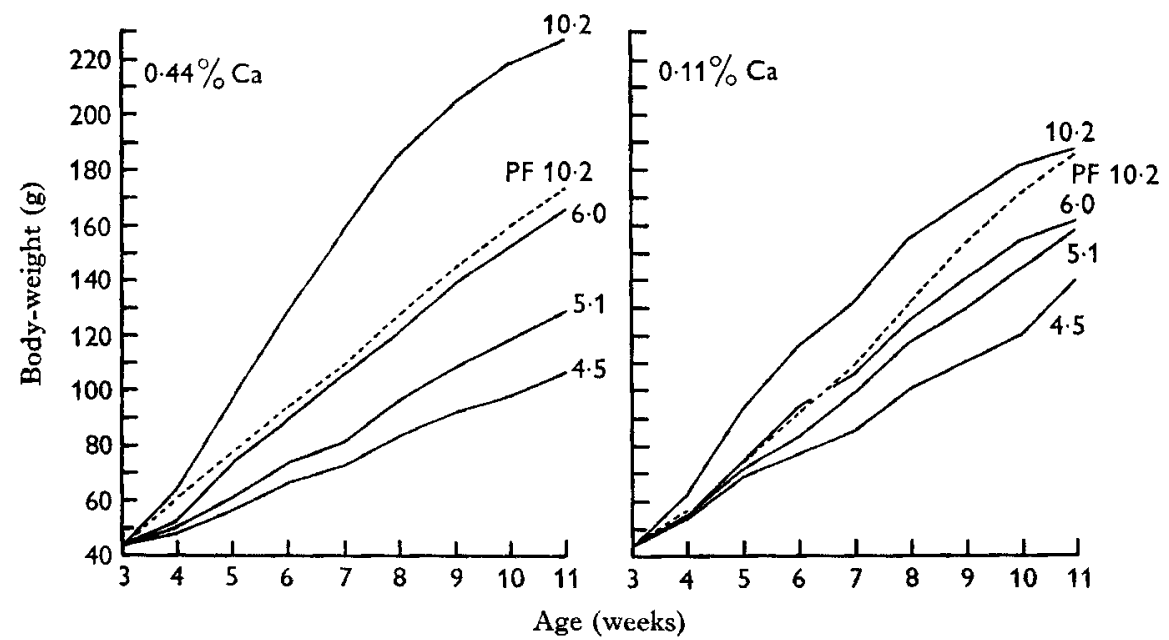

Fig. 1. Expt 1. Body-weight curves of young male rats maintained on diets of different protein values and $\mathrm{Ca}$ concentrations. The figures on the curves give the NDpCal \% of the diet. PF ro.z denotes animals pair-fed with the high-protein diet in amounts equal to those consumed by rats on the diet of low protein value. Each curve represents the mean for four rats.

Table 2. Expt 1. Mean body-weight and food consumption of young male rats* on diets of different protein values and $\mathrm{Ca}$ concentrations

\begin{tabular}{|c|c|c|c|c|c|c|c|c|}
\hline & $\underbrace{\text { Diet }}$ & & & & & & $\begin{array}{c}\text { Daily } \\
\text { NDpCal }\end{array}$ & \\
\hline Symbol & $\begin{array}{c}\text { Protein } \\
\text { value } \\
(\text { NDpCal \%) }\end{array}$ & $\begin{array}{l}\mathrm{Ca} \\
(\%)\end{array}$ & $\begin{array}{c}\text { Initial } \\
\text { body-wt } \\
\text { (g) }\end{array}$ & $\begin{array}{c}\text { Gain in } \\
\text { body-wt } \\
\text { (g) }\end{array}$ & $\begin{array}{l}\text { Food con- } \\
\text { sumption } \\
\text { (g/day) }\end{array}$ & $\begin{array}{c}\mathrm{Ca} \\
\text { intake } \\
(\mathrm{mg} / \text { day })\end{array}$ & $\begin{array}{c}\text { intake } / \mathrm{kg} \\
\text { body- } \\
\mathrm{wt}^{0 \cdot 73}\end{array}$ & PER \\
\hline A & $10: 2$ & $0: 44$ & $43^{\circ} \circ$ & $18_{3} \cdot 1$ & II'2 & 49 & $13 \cdot 9$ & $I \cdot I 8$ \\
\hline D & $6 \cdot 0$ & 0.44 & $43^{-2}$ & $12 I \cdot 8$ & II $\cdot 2$ & 49 & $10 \% 4$ & I.96 \\
\hline G & $5 \cdot 1$ & 0.44 & 43.0 & $84 * 9$ & $9 \cdot 2$ & 40 & 8.8 & 2.03 \\
\hline $\mathrm{K}$ & 4.5 & 0.44 & 43.0 & $62 \cdot 8$ & $8 \cdot 0$ & 35 & $7 \cdot 8$ & $2 \cdot 12$ \\
\hline A & PF ro.2† & 0.44 & 43.2 & $129 \cdot 8$ & $8 \cdot 0$ & 35 & $12 \cdot 3$ & $1 \cdot 15$ \\
\hline B & $10 \cdot 2$ & 0.22 & $43^{\circ} 0$ & $197^{\circ} 0$ & $12 \cdot 3$ & 27 & 14.6 & $I \cdot I 4$ \\
\hline$E$ & $6 \cdot 0$ & 0.22 & 43.5 & $127 \cdot 5$ & $12 \cdot 1$ & 27 & ro.9 & $1 \cdot 90$ \\
\hline $\mathrm{H}$ & $5 \cdot 1$ & 0.22 & $43^{\circ} \circ$ & $101 \cdot 5$ & $9^{-9}$ & 22 & 8.6 & $2 \cdot 28$ \\
\hline $\mathbf{L}$ & 45 & 0.22 & $43 \cdot 2$ & $71 \cdot 8$ & $8 \cdot 6$ & r9 & $7 \cdot 8$ & $2 \cdot 32$ \\
\hline B & PF ro.2† & 0.22 & $43 \cdot 2$ & $127 \cdot 3$ & $8 \cdot 6$ & 19 & 13.2 & $1 \cdot 07$ \\
\hline $\mathrm{C}$ & 10.2 & O.II & $43 \cdot 0$ & $144^{\circ} 0$ & II $\cdot 3$ & I 2 & $16 \cdot 2$ & 0.92 \\
\hline $\mathbf{F}$ & $6 \cdot 0$ & $0 . I I$ & $43 \cdot 7$ & 117.0 & 10.5 & I I & $9 \cdot 9$ & 2.00 \\
\hline $\mathbf{J}$ & $5 \cdot I$ & O. I I & $43^{\circ} 0$ & 114.6 & I I'I & 12 & 9.0 & $2 \cdot 25$ \\
\hline M & $4 \cdot 5$ & 0.11 & $43 \cdot 2$ & 85.4 & 10.0 & I I & $8 \cdot 4$ & $2 \cdot 3 I$ \\
\hline C & PF $10.2 \dagger$ & 0.11 & $43 \cdot 2$ & $14 I^{\prime} 4$ & $10 \cdot 0$ & IX & 14.4 & $I \cdot 00$ \\
\hline
\end{tabular}

\footnotetext{
* Each value is the mean for four rats. $\quad$ PF 10.2 denotes pair-fed controls.
} 


\section{Bones}

Size and radiographic density. The lengths of the femur and mandible (Table 3) were roughly proportional to the gains in body-weight and, in keeping with previous findings in protein-calorie deficient animals (McCance, Ford \& Brown, r961; Platt \& Stewart, I962), there were only slight differences in the size of the cranial cavity.

Femurs (Pl. I) and vertebras with a high radiographic density were found in animals given unrestricted amounts of diet $\mathrm{A}$. The density was lower when either the protein or the $\mathrm{Ca}$ of the diet was reduced. In the pair-fed controls, for which the protein value of the diet was increased without altering the intake of $\mathrm{Ca}$, the radiographic density of the bones was lower when the Ca formed $0.11 \%$ of the diet and greater when the concentration of $\mathrm{Ca}$ was $0.44 \%$.

Composition. At each concentration of dietary $\mathrm{Ca}$ the total ash of the femur was reduced when the protein value of the diet was lowered (Table 3 ), the changes being greatest when the diet contained $0.44 \% \mathrm{Ca}$ and least with $0.1 \mathrm{I} \%$. Reducing the $\mathrm{Ca}$ concentration of diets with a high protein value led to a large reduction (from 220 to $108 \mathrm{mg}$ ) in the mean total ash content, but the effect was less when diets of lower protein value were eaten. The femurs of the pair-fed controls contained more total ash than those of the animals given the low-protein diet of equal $\mathrm{Ca}$ content (Table 3 ).

The $A: R$ ratios (Table 3 ) which varied from $I \cdot I 3$ to $I \cdot 95$ confirmed, as did the radiographs, that the rats were not rachitic. The highest $A: R$ ratio was found in the bones of the rats given the high-protein, high-Ca diet $a d$ lib. Reducing the Ca content of the diet led to a lower $A: R$ ratio at all protein values, whereas the effect of reducing the protein value was only marked when the diet contained $0.44 \% \mathrm{Ca}$.

The weight of ash $/ \mathrm{cm}^{3}$ of the bones of those animals maintained on diets of low protein value was within the range $328-360 \mathrm{mg}$ and did not appear to be modified by the concentration of $\mathrm{Ca}$ in the diet. Improving the protein value of a diet providing $0.44 \% \mathrm{Ca}$ led to a progressive increase in the concentration of ash, but, when only $0.1 \mathrm{I} \% \mathrm{Ca}$ was available, a similar increase in the protein value led to a slight but consistent fall (Table 3, Fig. 2). Clearly $0.1 \mathrm{I} \% \mathrm{Ca}$ was only adequate to support full calcification when the rate of growth of the bone was low and extra protein, by stimulating growth, brought about a deficiency of $\mathrm{Ca}$. In animals given diets containing $0.22 \% \mathrm{Ca}$, the weight of ash $/ \mathrm{cm}^{3}$ improved with protein values up to $\mathrm{NDpCal} \%=6.0$, but above this value the $\mathrm{Ca}$ was again inadequate. Even at $\mathrm{NDpCal} \%=6 \cdot 0$ the concentration of mineral in the bones was less with $0.22 \%$ than with $0.44 \% \mathrm{Ca}$ in the diet. In the pair-fed controls receiving $0.44 \% \mathrm{Ca}$ increasing the protein brought about an improvement in the weight of ash $/ \mathrm{cm}^{3}$, with only $0.1 \mathrm{I} \% \mathrm{Ca}$ a reduction, and at the intermediate level $(0.22 \%)$ little or no effect.

Histological appearance. The changes were similar in the distal portion of the femur and the proximal part of the tibia; the following descriptions therefore apply to both bones. The alterations in the epiphysial cartilages and metaphysial trabeculae of the bones of animals maintained on diets of low protein value were similar to those described earlier in rats (Frandsen et al. 1954) and pigs (Platt \& Stewart, 1962). The cartilages were thin, osteoblastosis was reduced, the metaphysial region was rarefied, 


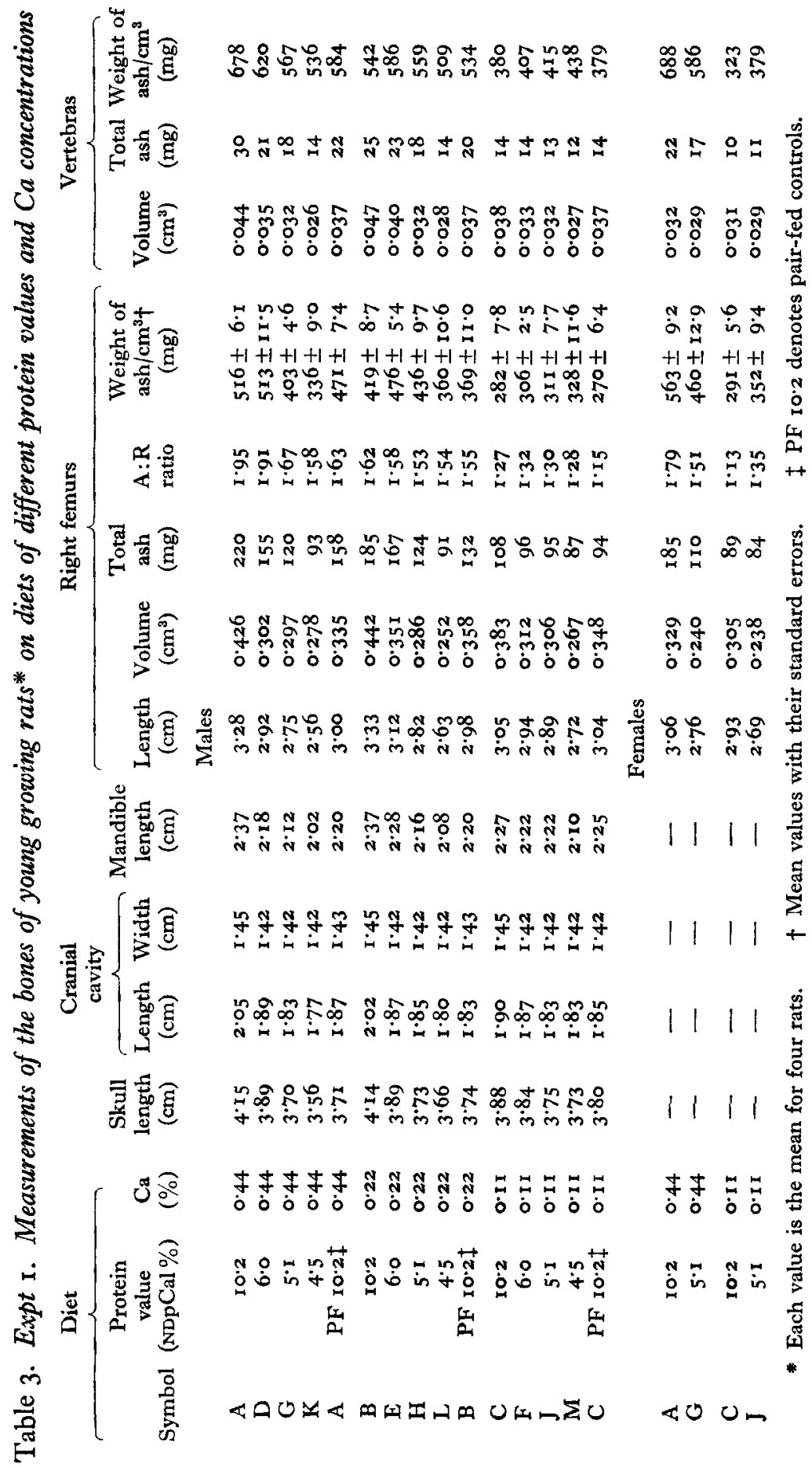


the number of trabeculae was reduced and those present were short and thick. Transverse trabeculation, which was such a prominent feature in the bones of the pigs (Stewart \& Platt, 1958), was not common, but some 'clubbing' of the trabeculae and transverse linking was seen. The cortices of the shafts were reduced in thickness, but the tissue was compact and well calcified (see Pl. 2). The bones of all the animals receiving the diets of low protein value were, irrespective of $\mathrm{Ca}$ content, similar to those described above. With the higher intakes of protein and inadequate supplies of $\mathrm{Ca}$ the growth and maturation of the cartilage was normal, there was no thickening of the primary cartilaginous trabeculae or 'clubbing' of the secondary trabeculae.

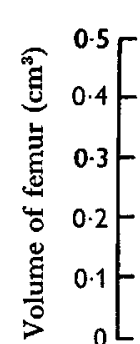

$0.44 \% \mathrm{Ca}$

$0.22 \% \mathrm{Ca}$

$0.11 \% \mathrm{Ca}$
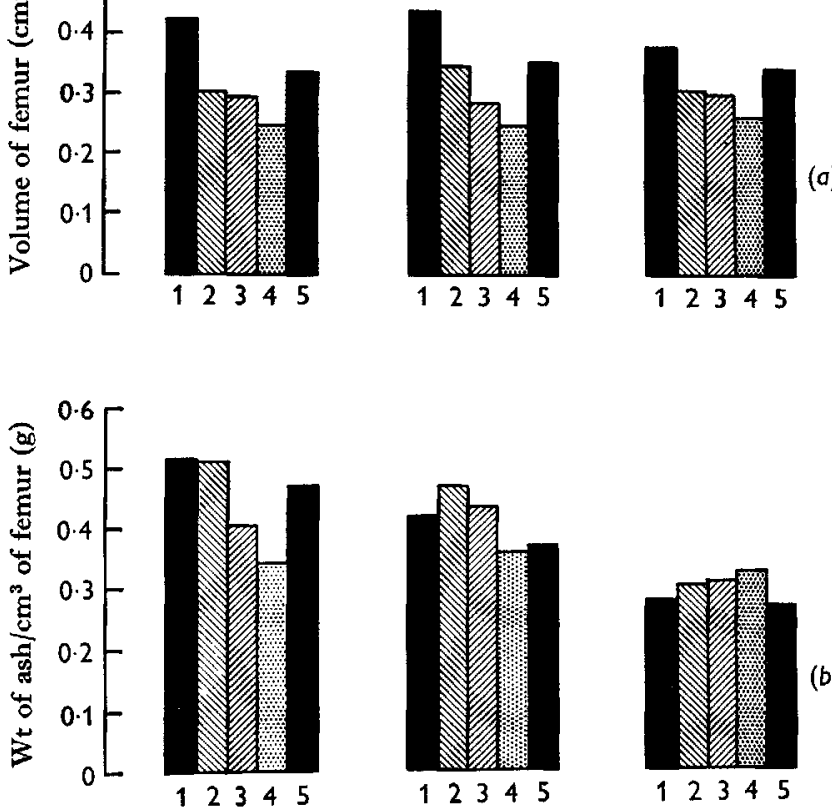

Fig. 2. Expt I, Effect on the volume and the weight of ash $/ \mathrm{cm}^{3}$ of the femurs of young rats maintained on diets of different protein values and calcium concentrations. I, NDpCal $\%=10.2$; 2, $\mathrm{NDpCal} \%=6.0 ; 3, \mathrm{NDpCal} \%=5 . \mathrm{I} ; 4, \mathrm{NDpCal} \%=4.5 ; 5$, controls pair-fed to the intake of the rats on the low-protein diet. Each column represents the mean for four rats.

There was, however, an intense osteoclasis, so that the metaphysial trabeculae were as short as, and the cortices thinner than, those of the bones of the animals on the low-protein diet. The thin cortices found in the bones of the animals given the diets of high protein value contained many resorption cavities and the organization from lamellar to compact bone was incomplete. Thus, although superficially the bones of protein- and Ca-deficient animals exhibited some similarities, the histological changes were different.

The bones of the female rats were similar to those of young male rats; the slightly lower values for total weight of ash and higher values for weight of $\mathrm{ash} / \mathrm{cm}^{3}$ found in the femurs of the females can be related to differences in the rate of growth. 
Weight and food intakes

Expt 2. Adult rats: main experiment

Alterations in the $\mathrm{Ca}$ content of the diet had little effect on the food consumption or body-weight of these adult animals. However, more marked changes developed between animals given diets of different protein value (Table 4 ) and, whereas the weight of the rats on the high-protein diet increased by about I I $\%$, that of the animals on the diets of low protein value fell by about $35 \%$. The pair-fed controls lost only $18 \%$ of their original weight.

\section{Bones}

Size and radiographic density. As would be expected in the bones of adult animals, no differences that could be related to the dietary regimens were found in the lengths of the femurs or other bones. Irrespective of $\mathrm{Ca}$ intakes, the bones of the animals given the low-protein diets were radiographically less dense than those of animals on the diets of higher protein value (PI. 3). Pair-feeding with the diet of high protein value led to an increase in the radiographic density of the bones, indicating that $\mathrm{Ca}$ was not, under the conditions of this experiment, the limiting factor.

Composition. In both males and females the weight of ash $/ \mathrm{cm}^{3}$ in the femur and in the and cervical vertebra was reduced less by altering the intake of $\mathrm{Ca}$ than by altering the intake of protein. Reducing the $\mathrm{Ca}$ intake at a protein value of NDpCal $\%=\mathrm{I} \cdot 6$, but not at $\mathrm{NDpCal} \%=6 \cdot 0$, produced a marked fall (Table 5 ).

The bones of the pair-fed controls contained more total ash and more ash $/ \mathrm{cm}^{3}$ than those of the animals given the diets of low protein value at each concentration of dietary $\mathrm{Ca}$.

Histological appearance. In these adult animals the epiphysial cartilages, although still present (complete closure does not occur in the rat), were inactive and osteoblastosis was less than in the younger normal animals.

Photomicrographs of representative regions of the shaft of the femur of animals given the diets of different protein and $\mathrm{Ca}$ content are shown in $\mathrm{Pl} .4(a-d)$. Reducing the protein content leads to the development of thin cortices $(b$ and $d$ ), whereas altering the $\mathrm{Ca}$ within the range tested has little effect, although the bones shown in $c$ and $d(0.1 \mathrm{I} \% \mathrm{Ca})$ were slightly less compact than those in $a$ and $b(0.44 \% \mathrm{Ca})$.

\section{Expt 2. Adult rats: recovery experiment}

\section{Weight and food intakes}

The animals given only the extra $\mathrm{Ca}(\operatorname{diet} \mathrm{N})$ continued to lose weight whereas those given the diets of higher protein value showed, irrespective of the Ca concentration, a marked increase in food consumption and, by the end of the Io-week recovery period, had regained the weight lost during the first 20 weeks of the experiment.

\section{Bones}

Size and radiographic density. No significant differences were found in the length of the femur, skull and mandible. Radiographs showed that rarefaction progressed 


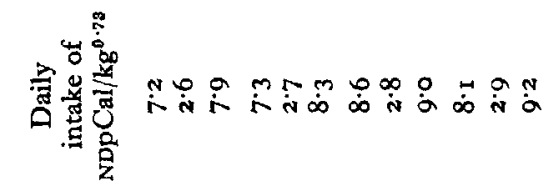

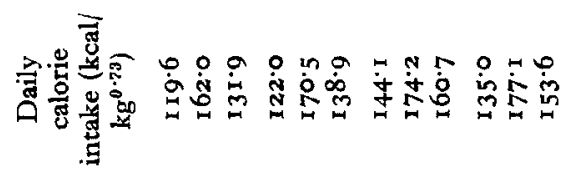

논

2

हี

赵

응

$\frac{8}{2}$

8

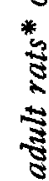

จุ

ริ

政

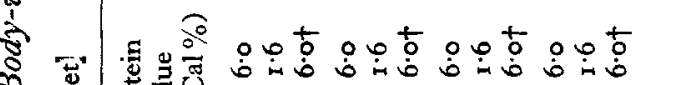

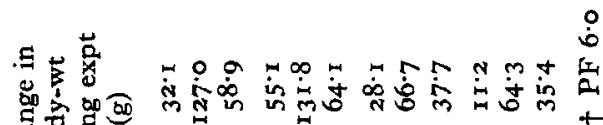

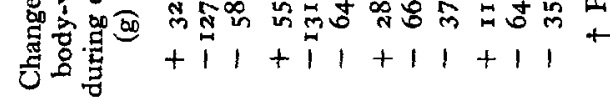

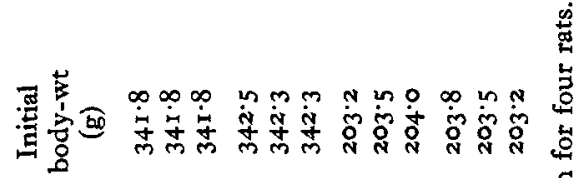

总

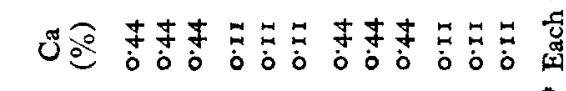

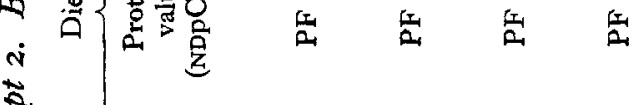

蛋

京


跑

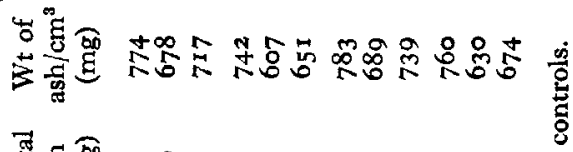

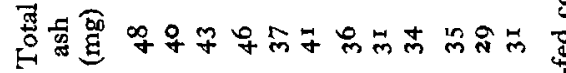

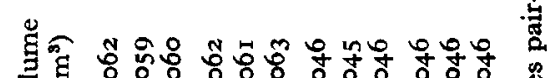

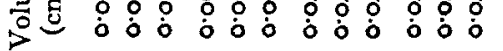

$+m+\infty+0 N$ n m $m a k 0$

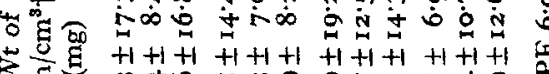
这 $+1+1+1+1+1+1+1+1+1+1+1$

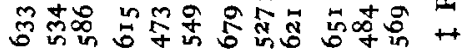

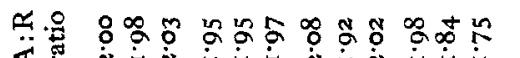

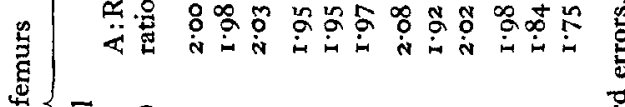

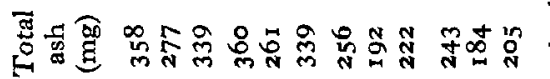

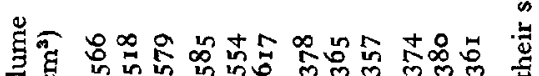
包 荡

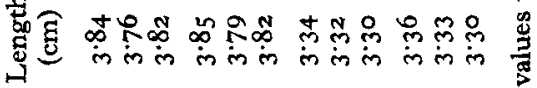

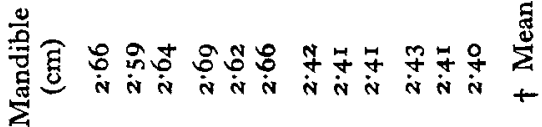

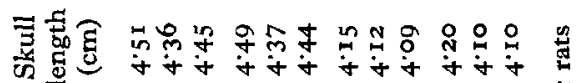

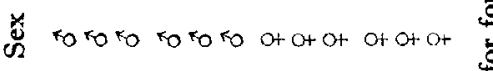

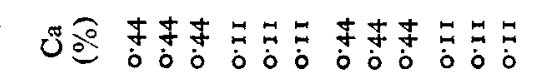
ن

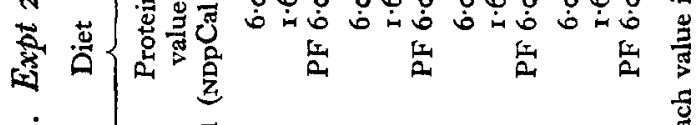

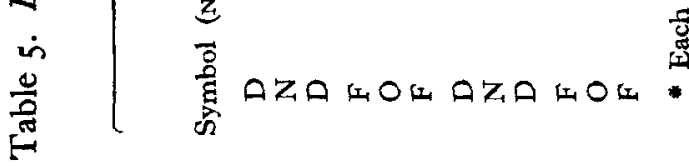


in the bones of the animals which continued on the low-protein diet even though extra $\mathrm{Ca}$ was provided. The radiographic density increased in the bones of all the animals transferred to diets with a higher protein value, but was greatest in those of the rats receiving additional protein and $\mathrm{Ca}(\mathrm{Pl} .5)$.

Composition. The bones of the animals given the low-protein diet continued to lose mineral and there was a reduction in the $A: R$ ratio of the femur which did not occur when the diet had a higher protein value (Table 6). The values for weight of ash $/ \mathrm{cm}^{3}$ were most revealing, those for rats given the low-protein diet with additional Ca continuing to fall at approximately the same rate as in the earlier period of the experiment, whereas in the bones of the animals given the diets of higher protein value the fall in weight of ash $/ \mathrm{cm}^{3}$ was arrested, the values began to rise and, as might be expected in animals depositing new matrix and mineral, the diet with the higher $\mathrm{Ca}$ content showed the greater increase (Fig. 3). These results, as those for the main experiment, applied to both sexes and with only very minor variations (Table 6) to the vertebras as well as to the long bones.

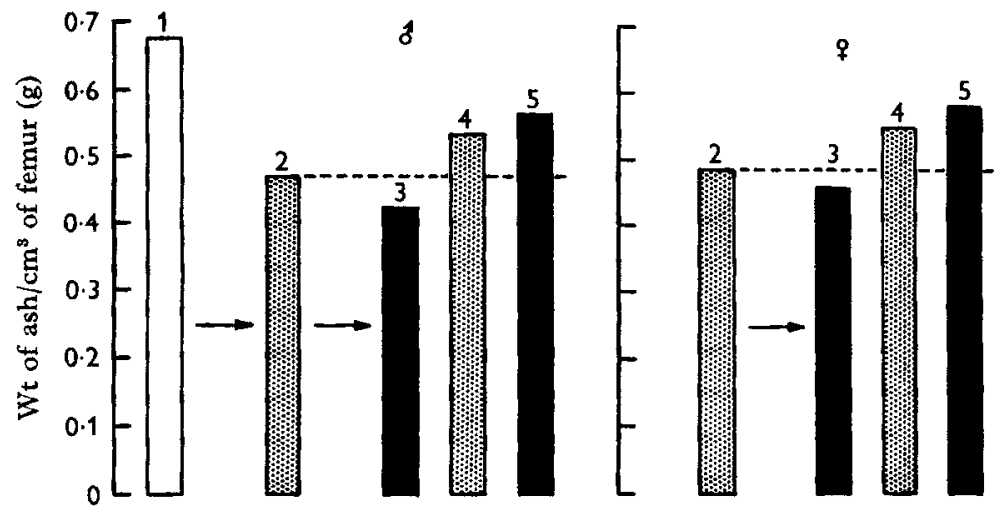

Fig. 3. Expt 2. Weight of ash $/ \mathrm{cm}^{3}$ of the femurs of adult rats maintained on diets of different protein values and $\mathrm{Ca}$ concentrations. 1 , normal rats on stock diet aged 28 weeks; 2 , rats maintained from the 28th to the 48 th week of age on a diet of NDpCal $\%=r \cdot 6$ and $\mathrm{Ca} 0.1 \mathrm{I} \% ; 3,4$ and 5 , rats which after treatment as 2 were then given for 10 weeks diets of: (3) NDpCal $\%=\mathrm{I} \cdot 6$ and $\mathrm{Ca} 0.44 \%$, (4) NDpCal $\%=6.0$ and $\mathrm{Ca} 0^{\circ}$ I I $\%$ or (5) NDpCal $\%=6.0$ and $\mathrm{Ca} 0.44 \%$. Each column represents the mean for four male, or five female, rats.

Histological appearance. In the bones of the animals which received the low-protein diet the cortices were thin, contained numerous areas of resorption, and osteoblastosis was minimal. In those from animals given the high-protein diets osteoblastosis was active, the cortices were thicker and resorption spaces, even when the diet contained only $0.11 \% \mathrm{Ca}$, were less common than in the bones of animals given the low-protein diet.

\section{Expt 3. Aged rats: main experiment}

\section{Weight and food intakes during first I2 weeks of experiment}

When the protein value of the diet was low, rats receiving the diets with $0.44 \% \mathrm{Ca}$ lost nearly twice as much weight as those given only $0.11 \%$, and even with the diet of high protein value only the rats receiving the low-Ca diet $(\mathrm{C})$ increased in weight. These differences could not be related to appetite (Table 7). 


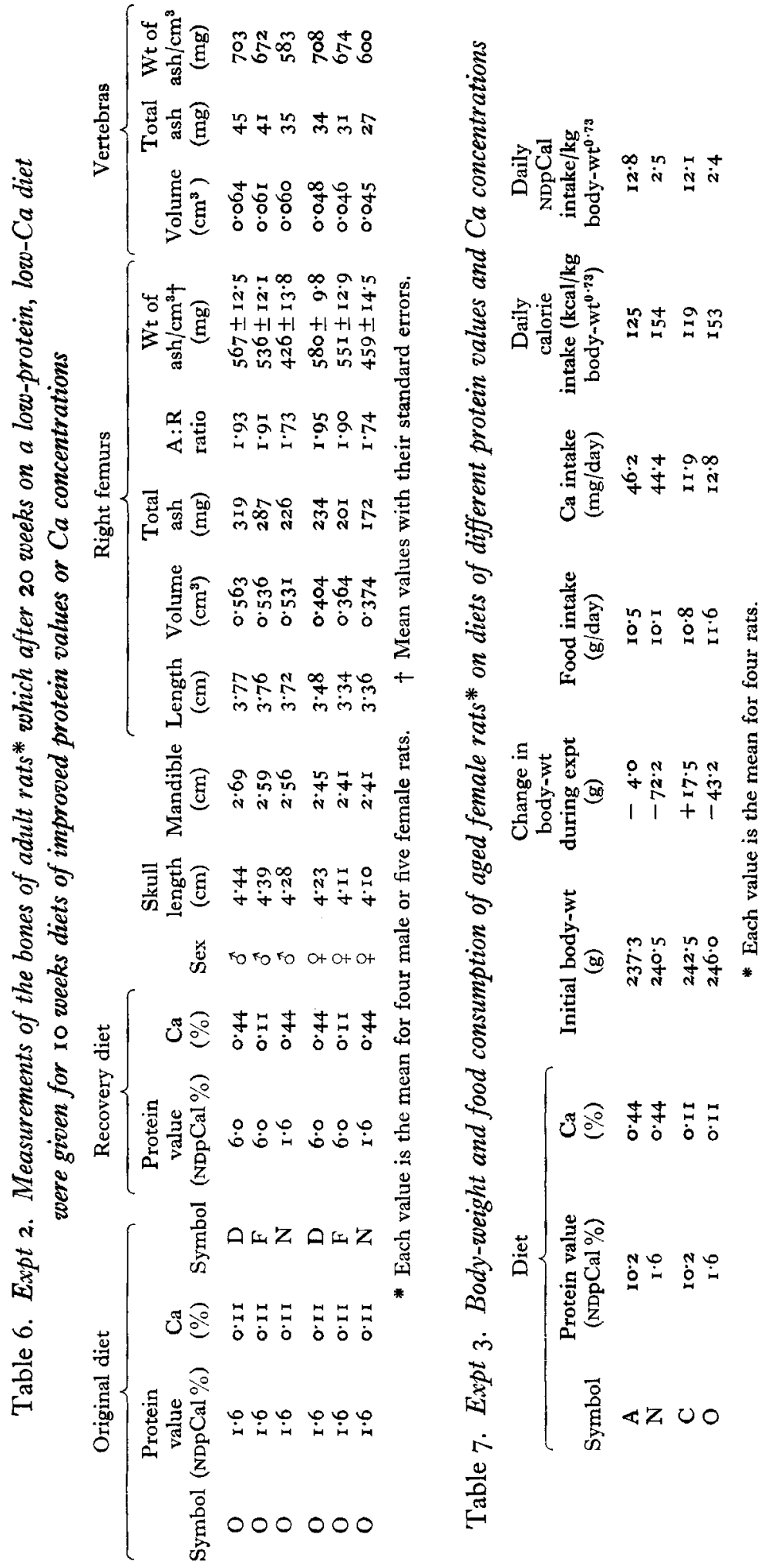




\section{Bones}

Size and radiographic density. After 12 weeks on the diet there were no differences in the lengths of the various bones. Radiographic densities were greater in the bones of the animals receiving the high-protein diets, but alterations in the dietary $\mathrm{Ca}$ appeared to have brought about little if any change (Table 8, Pl. 6).

Composition. Differences between the $A: R$ ratios and total ash contents of the femurs were small, but the weight of ash $/ \mathrm{cm}^{3}$ was reduced in all the animals given the low-protein diets (Table 8). Reducing the concentration of Ca had little, if any, effect and, when the protein intake was low, may even have improved the bones. Similar results were obtained from the vertebras (Table 8 ).

Histological appearance. All the bones showed some resorption of the cortices, which was most pronounced in the rats on the low-protein, high-Ca diet and least in those having the high-protein, high-Ca diet. The differences in the thickness of the walls of the shaft were less distinct than in the younger adults. As would be expected in rats more than 2 years of age, the epiphysial cartilages were inactive and 'sealed' from the marrow cavity by a layer of bone.

\section{Expt 3. Aged rats: recovery experiment}

\section{Weight and food intake}

Intakes of food improved in all the rats transferred from the low- to the highprotein diets, body-weight increased, and after 7 weeks' recovery there was little difference in the weights of the eight rats.

\section{Bones}

Radiographic density and composition. The radiographic density of the bones of the animals originally given the low-protein diets improved and became about equal to that of the animals on the control diets (Pl. 6). The A:R ratios were, except for the bones of rats originally given the high-protein, low-Ca diet, very slightly higher than those found at $\mathrm{I} 2$ weeks, and the values for weight of $\mathrm{ash} / \mathrm{cm}^{3}$ of the femurs all fell within the range $627-660 \mathrm{mg}$ (Table 9).

Histological appearance. There was, after recovery, no appreciable difference in the thickness of the walls of the shafts of the femurs. Localized areas containing irregular empty lacunae and areas of resorption were present in all, but they were not as large or as numerous as in the bones of the rats on the low-protein diet killed before the change of diet.

\section{Expts 1, 2 and 3. Serum composition}

The pooled serums from each of the thirty-nine groups of rats were all analysed for inorganic $\mathrm{P}, \mathrm{Ca}$ and protein. The inorganic $\mathrm{P}$ varied between 7 and $8.4 \mathrm{mg} / \mathrm{roo} \mathrm{ml}$ serum, the $\mathrm{Ca}$ between 8.9 and $1 \mathrm{I} .7 \mathrm{mg} / 100 \mathrm{ml}$, and the $\mathrm{Ca} \times \mathrm{P}$ product was never lower than $6_{3}$. The concentration of protein was related to the protein value of the diet, being as high as $8.1 \mathrm{~g} / 100 \mathrm{ml}$ in the serums of animals receiving diets of high protein value, and as low as $4^{\circ} 9$ when the protein value of the diet was low. 


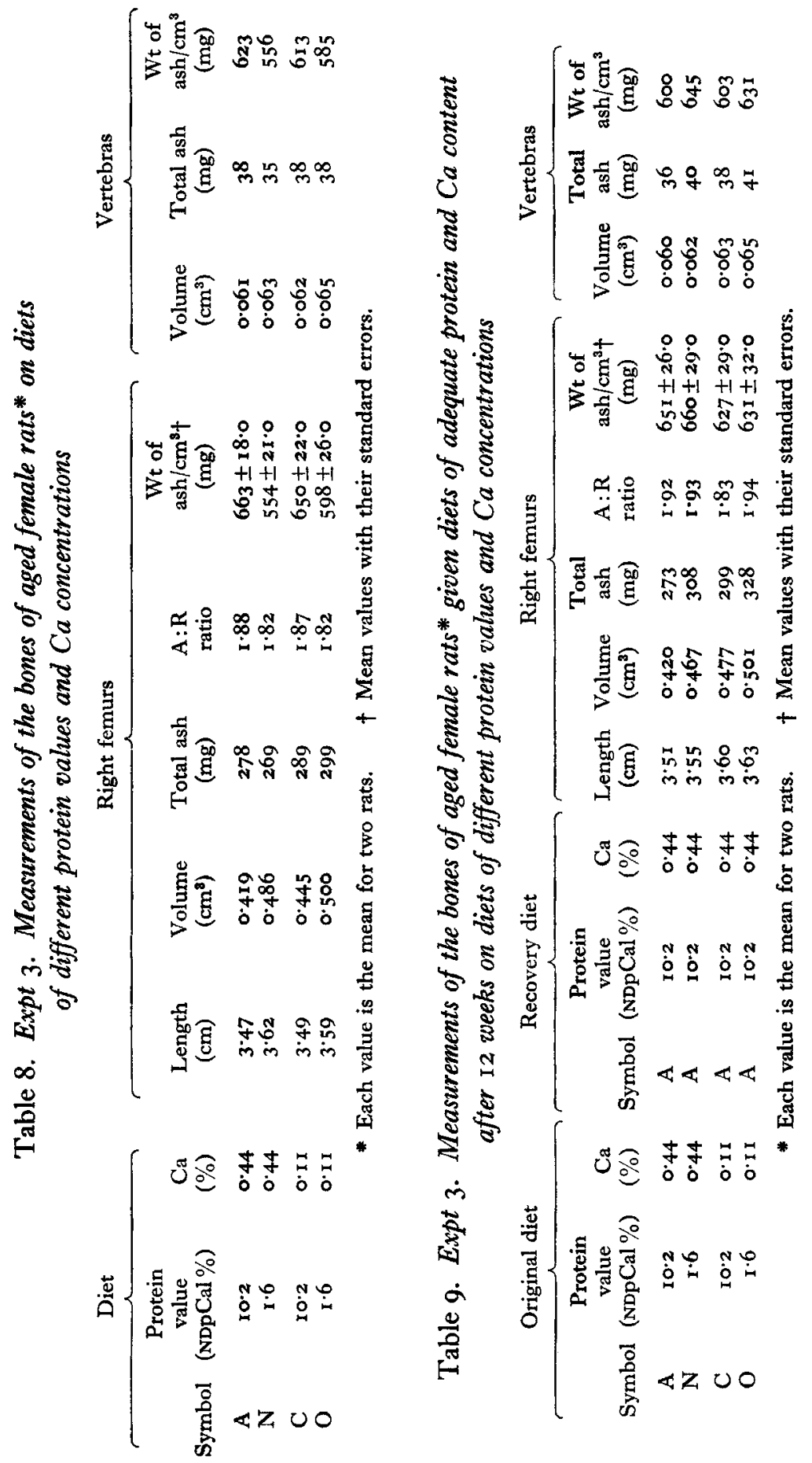




\section{DISCUSSION}

The complications brought about by the reduced intake of food by animals given diets of low protein value were overcome to some extent by using pair-fed controls. Low intakes of $\mathrm{Ca}$ may, however, lead to inanition and the protein value of the diet will then, as far as the consumer is concerned, be seriously lowered (Platt et al. 1961). Bell, Cuthbertson \& Orr (194I-2) showed that under the conditions of their tests the food consumption of rats was not significantly reduced when $\mathrm{Ca}$ provided only $0.075 \%$ of the diet, and that above $0.36 \%$ no further improvement in bone calcification occurred. Preliminary tests showed that with diets having a protein value as high as $\mathrm{NDpCal} \%=10.2$ these $\mathrm{Ca}$ concentrations were rather low, and in the experiments now described they were raised to 0.11 and $0.44 \%$. Such variations in the $\mathrm{Ca}$ content led to alterations in the $\mathrm{Ca}: \mathrm{P}$ ratio of the diet which is considered to be of great importance in the development of rickets in rats. There is, however, no good evidence that, in the presence of adequate supplies of vitamin D, rickets or osteomalacia, as distinct from bone rarefaction, ever develops in rats given diets with adverse Ca:P ratios (Crawford, Gribetz, Diner, Hurst \& Castleman, 1957; Greaves, Scott \& Scott, 1959; Harrison \& Fraser, 1960a, b).

Appetite may also be affected by the concentration of $P$ in the diet, and the form of the $\mathbf{P}$ can affect the availability of other nutrients (Mellanby, 1949; O'Dell \& Savage, 1960; Follis, 1958; Roberts \& Yudkin, 1960). The diets contained a salt mixture which supplied sufficient inorganic $\mathbf{P}$ to support an adequate rate of growth even if the rest of the diet contains only minimal quantities of total P (Jones \& Foster, 1942).

The evidence obtained from analysis of serum, radiographs, histological preparations and $A: R$ ratios confirmed that neither rickets nor osteomalacia had occurred in any of the rats.

The bones of young rats given diets of low $\mathrm{Ca}$ but adequate protein value exhibited marked rarefaction which could be prevented by increasing the concentration of $\mathrm{Ca}$ in the diet. The high-protein diet promoted the deposition of bone matrix and, when there was insufficient $\mathrm{Ca}$, vitamin $\mathrm{D}$, probably through the parathyroids, stimulated the destruction of the older bone to provide mineral for the new. This led to the development of mineral-osteoporosis, i.e. bones with nearly normal bulk, low radiographic densities, low values for total weight of ash and weight of ash $/ \mathrm{cm}^{3}$ of bone, thin cortices, a relative excess of recently formed bone and therefore low A:R ratios. In older animals this type of bone rarefaction was not produced, probably because the lowest dietary concentration of $\mathrm{Ca}(0 \cdot 1 \mathrm{I} \%)$ was adequate for the maintenance, as distinct from the growth of bone.

The rarefaction found in the bones of all the protein-calorie deficient rats can, on the other hand, be regarded as matrix-osteoporosis. An increased intake of protein, even when unaccompanied by extra intake of calories or $\mathrm{Ca}$, led to the production of bones with a higher total weight of ash and, except when the $\mathrm{Ca}$ concentration of the diet was low ( $0.11 \%$ ), increased radiographic densities, higher values for weight of ash $/ \mathrm{cm}^{3}$ of bone, thicker cortices and slightly higher $A: R$ ratios. When the intake 
of $\mathrm{Ca}$ was low, stimulating the deposition of bone matrix by increasing the protein value of the diet converted a matrix- into a mineral-osteoporosis. It might be expected that in bones in which growth was slow or had ceased there would be a high proportion of older fully calcified bone and therefore a high $A: R$ ratio. Dickerson \& $\mathrm{McC}$ ance (196I) reported that the Ca:collagen ratios of the cortical bone of cockerels maintained at a constant body-weight from the age of $2 \frac{1}{2}$ to 27 weeks were higher than those of weight or age controls. Platt \& Stewart (1962) found the A:R ratios of the femurs of protein-calorie deficient pigs to be similar to those of age controls, but in the bones of the protein-calorie deficient rats the A: $R$ ratios were slightly lower than in those of the well-fed controls. Examination of the bones of the pair-fed animals indicated that the diet consumed by the protein-calorie deficient rats provided ample minerals; however, the pair-fed controls may, because of their higher intake of protein, have absorbed and utilized $\mathrm{Ca}$ more effectively than the deficient rats. Lengemann \& Comar (1961) demonstrated that protein stimulates the active transport of $\mathrm{Ca}$ from the mucosal to the serosal surfaces of the gut, even against a concentration gradient, and McCance, Widdowson \& Lehmann (1942) and Mellander (I955) found that dietary protein was able to improve the absorption of $\mathrm{Ca}$. In the presence of vitamin $\mathrm{D}$ the concentration of $\mathrm{Ca}$, which was low in the serum of the proteindeficient rats, is known to play a part in the control of parathyroid activity, although the deficit in these animals was thought to occur in the less important unionized fraction. The parathyroids, however, are probably involved in the disturbance of endocrine balance which occurs in protein-calorie deficient animals (Platt, Heard \& Stewart, 1964).

Mineral-osteoporosis can be cured or prevented by the addition of minerals, in our experiments $\mathrm{Ca}$, to the diet, and matrix-osteoporosis by addition of protein. The addition of extra protein to a diet already low in Ca intensified the rarefaction of the bones, and the addition of $\mathrm{Ca}$ to a diet deficient in protein led to reduced gains or actual loss of body-weight. This effect is probably related to alterations in the PER which could be lowered by reducing the $\mathrm{Ca}$ of a high-protein diet or increasing the $\mathrm{Ca}$ of a low-protein diet. $\mathrm{Ca}$ is known to affect the absorption of many nutrients, and it seems likely that this effect can be modified by protein. Rats maintained on the low-protein, high-Ca diets developed a mild alopecia and greying of the hair, which could be prevented either by reducing the intake of $\mathrm{Ca}$ or increasing that of protein.

The onset of osteoporosis has been related to (I) low intakes or (2) poor retention of $\mathrm{Ca}$ (Nordin, 1960, I961, 1962), (3) a change in the composition of the bone matrix (Casuccio, 1962), (4) an inadequate supply of protein (Bartter, 1957) and (5) a relative excess of corticosteroids (Reifenstein, 1957; Caldwell, 1962). An endocrine imbalance with a relative excess of corticosteroids is known to occur in protein-calorie deficient animals and therefore factors $\mathrm{I}, 4$ and 5 separately or in combination may have occurred in our experiments.

Whether senile osteoporosis ever occurs as a direct result of protein-calorie deficiency is not known, but the intakes of protein are low in some osteoporotics (Nordin, 1960), and many elderly persons receive suboptimal amounts of both protein and $\mathrm{Ca}$. That 
a deficiency of $\mathrm{Ca}$ will lead to osteoporosis has been accepted for many years, but our results indicate that rarefaction of bone can be due to a low intake of protein and that this type of osteoporosis can be reversed and the density of the bones increased even in aged rats. These observations support the view (Platt \& Stewart, 1962) that in the prevention or treatment of osteoporosis an increase in the protein value of the diet may be as important as, or more important than, supplementation with $\mathrm{Ca}$.

\section{SUMMARY}

I. Young, adult and aged rats were maintained on diets containing ergocalciferol but having different protein values and $\mathrm{Ca}$ concentrations.

2. The size and quality of the bones of the rats were assessed from radiographs, A: R ratios, histological examination, total weight of ash and weight of ash $/ \mathrm{cm}^{3}$.

3. At all the ages tested, the bones of animals receiving diets of low protein value exhibited matrix-osteoporosis.

4. Diets of low $(0.11 \%) \mathrm{Ca}$ content led, when the protein value of the diet was high, to severe mineral-osteoporosis in the bones of young rats, but to only slight changes in those of older animals.

5. Young rats given diets of high protein value had larger bones containing more mineral than litter-mates maintained on a low-protein regimen although both groups received the same amount of food and $\mathrm{Ca}$.

6. When adult rats whose bones had become rarefied on diets of NDpCal $\%=\mathrm{I} \cdot 6$ and containing $0.1 \mathrm{I} \% \mathrm{Ca}$ were given additional $\mathrm{Ca}$ the degree of matrix-osteoporosis increased. On the other hand, improving the protein value of the animals' diets led to a remineralization of their bones.

7. Even in aged rats, matrix-osteoporosis brought about by diets of low protein value could be corrected by increasing the intake of protein.

8. The interaction of protein and $\mathrm{Ca}$ and their relative importance in the treatment of osteoporosis is discussed.

\section{REFERENCES}

Albright, F. (1943). Harvey Lect. 38, 123.

Albright, F. (1947). Ann. intern. Med. 27, 861.

Albright, F., Bartter, F. C., Dempsey, E. F., Forbes, A. B., Henneman, P. H. \& Reifenstein, E. C. (1953). In Metabolic Interrelations: Transactions of the Fifth Conference, p. 277. [E. C. Reifenstein Jr., editor.] New York: Josiah Macy Jr. Foundation.

Bartter, F. C. (1957). Am. F. Med. 22, 797.

Bell, G. H., Cuthbertson, D. P. \& Orr, J. (1941-2). F. Physiol, roo, 299.

Bruce, H. M. \& Parkes, A. S. (1947). F. Hyg., Camb, 45, 70.

Caldwell, R. A. (1962). F. clin. Path. 15, 42 r.

Casuccio, C. (1962). Proc. R. Soc. Med. 55, 663.

Chick, H., Korenchevsky, V. \& Roscoe, M. H. (1926). Biochem. J. 20, 622.

Chick, H. \& Roscoe, M. H. (1926). Biochem. F. 20, 137.

Crawford, J. D., Gribetz, D., Diner, W. C., Hurst, P. \& Castleman, B. (1957). Endocrinology, 6r, 59. Dickerson, J. W. T. \& McCance, R. A. (196I). Br. F. Nutr. 15, 567.

El-Maraghi, N. R. H. (x964). The inter-relationship of different levels of calcium and protein and their effect on the growth, composition and structure of bone. PhD Thesis, University of London.

El-Maraghi, N. R. H. \& Stewart, R. J. C. (1963). Proc. Nutr. Soc. 22, xxx.

El-Maraghi, N. R. H. \& Stewart, R. J. C. (1964). Proc. Nutr. Soc. 23, xiv.

Fiske, C. H. \& Subbarow, Y. (1925). F. biol. Chem. 66, 375 .

Follis, R. H. Jr. (1958). Deficiency Disease. Springfield, Ill.: Charles C. Thomas. 
Fontaine, R., Mandel, P. \& Gries, A. (1950). C. r. Séanc. Soc. Biol. 144, I397.

Frandsen, A. M., Nelson, M. M., Sulon, E., Becks, H. \& Evans, H. M. (I954). Anat. Rec. Ir9, 247.

Gran, F. C. (1960). Acta physiol. scand. 49, 192.

Greaves, J. P., Scott, M. G. \& Scott, P. P. (1959) F. Physiol. 146, 36 P.

Harrison, M. \& Fraser, R. (rg6oa). F. Endocr. 2r, I9I.

Harrison, M. \& Fraser, R. (1960b). F. Endocr. 21, 197.

Jackson, C. M. (1925). The Effects of Inanition and Malnutrition upon Growth and Structure. London: J. \& A. Churchill Ltd.

Jones, J. H. \& Foster, C. (1942). F. Nutr. 24, 245.

Lengemann, F. W. \& Comar, C. L. (1961). Am. F. Physiol. 200, 1051.

McCance, R. A., Ford, E. H. R. \& Brown, W. A. B. (1961). Br. F. Nutr. 15, 213.

McCance, R. A., Widdowson, E. M. \& Lehmann, H. (1942). Biochem. F. 36, 686.

Mellanby, E. (1949). F. Physiol. ro9, 488.

Mellander, O. (1955). Nutr. Rev. r3, 161.

Nordin, B. E. C. (r960). Acta endocr., Copenh., Suppl. 51, 5 I7.

Nordin, B. E. C. (1961). Lancet, i, Ior 1.

Nordin, B. E. C. (1962). Am. F. clin. Nutr. 10, 384 .

O'Dell, B. L. \& Savage, J. E. (1960). Proc. Soc. exp. Biol. Med. ro3, 304.

Platt, B. S., Heard, C. R. C. \& Stewart, R. J. C. (r964). In Mammalian Protein Metabolism. Vol. 2, p. 445- [H. N. Munro and J. B. Allison, editors.] New York: Academic Press Inc.

Platt, B. S. \& Miller, D. S. (1959). Proc. Nutr. Soc. 18, vii.

Platt, B. S., Miller, D. S. \& Payne, P. R. (196r). In Recent Advances in Clinical Nutrition, p. 351. [J. F. Brock, editor.] London: J. \& A. Churchill Ltd.

Platt, B. S. \& Stewart, R. J. C. (1962). Br. F. Nutr. 16, 483 .

Reifenstein, E. C. Jr. (1957). Clin. Orthop. 1o, 206.

Roberts, A. H. \& Yudkin, J. (1960). Nature, Lond., 185, 823.

Stewart, R. J. C. (1965). Wld Rev. Nutr. Diet. 5, 275.

Stewart, R. J. C. \& Platt, B. S. (1958). Proc. Nutr. Soc. 17, v.

Urist, H. R. (1960). In Bone as a Tissue, p. I8. [K. Rodah1, J. T. Nicholson \& E. M. Brown, editors.] New York: McGraw-Hill Book Co. Inc.

\section{EXPLANATION OF PLATES}

Pl. I. Expt 1. Radiographs of femurs of young rats maintained from the 3 rd to the I Ith week of age on diets having different protein values and $\mathrm{Ca}$ concentrations.

Note: (I) the bones of the animals receiving the low-protein diets are small irrespective of dietary Ca concentrations; (2) bone rarefaction occurs when the protein value of diets containing 0.44 or $0.22 \%$ of $\mathrm{Ca}$ is reduced; (3) reducing the $\mathrm{Ca}$ concentration leads to rarefaction of bone when the diet has a protein value of NDpCal $\%=10.2,6.0$ or 5.1 but not $4.5 ;(4)$ increasing the protein value but not the total intake of $\mathrm{Ca}$ (pair-fed controls) leads to an increase in bone density when the dietary $\mathrm{Ca}$ is $0.44 \%$ and to a reduction at $0.11 \%$.

P1. 2. Expt r. Photomicrographs of the wall of the tibia of young rats maintained from the 3rd to the I I th week of age on diets having different protein values and $\mathrm{Ca}$ concentrations: $(a)$ NDpCal $\%=10 \cdot 2$, $\mathrm{Ca}=0.44 \% ;(b)$ NDpCal $\%=4.5, \mathrm{Ca}=0.44 \% ;(c)$ NopCal $\%=10.2, \mathrm{Ca}=0 . \mathrm{I}$ I $\% ;(d)$ NopCal $\%=4.5$, $\mathrm{Ca}=0.1 \mathrm{I} \%$.

Note: when the Ca forms $0.44 \%$ of the diet the thicker wall is found in the bone of the animal having the diet of higher protein value (cf. $a$ and $b$ ); when the Ca forms only $0.1 \mathrm{I} \%$ of the diet the thicker wall is found in the bone of the animal having the diet of lower protein value (cf. $c$ and $d$ ).

P1. 3. Expt 2. Radiographs of femurs of adult rats maintained from the 28 th to the 48 th week of age on diets having different protein values and $\mathrm{Ca}$ concentrations.

Note: (1) lowering the Ca from 0.44 to $0.11 \%$ of the diet has little effect on bone density; (2) rarefaction has occurred in the bones of animals receiving the diets of low protein value; (3) when in the pair-fed controls the protein value but not the Ca content of the diet was improved the bones had a higher radiographic density.

Pl. 4. Expt 2. Photomicrographs of the wall of the shaft of the tibia of rats maintained from the 28th to the 48 th week of age on diets having different protein values and Ca concentrations : $(a)$ NDpCal $\%=6 \cdot 0$, $\mathrm{Ca}=0.44 ;(b)$ NDpCal $\%=1 \cdot 6, \mathrm{Ca}=0.44 \% ;(c)$ NDpCal $\%=6.0, \mathrm{Ca}=0.11 \% ;(d)$ NDpCal $\%=1 \cdot 6$, $\mathrm{Ca}=0.1 \mathrm{I} \%$.

Note: the thickness of the wall of the shaft is related to the protein value rather than to the $\mathrm{Ca}$ concentration of the diet, but areas of resorption and enlarged lacunae are present in the bones from animals given the diets with the lower concentration of $\mathrm{Ca}(c$ and $d)$. 
British Fournal of Nutrition, Vol. 19, No. 4

Plate I
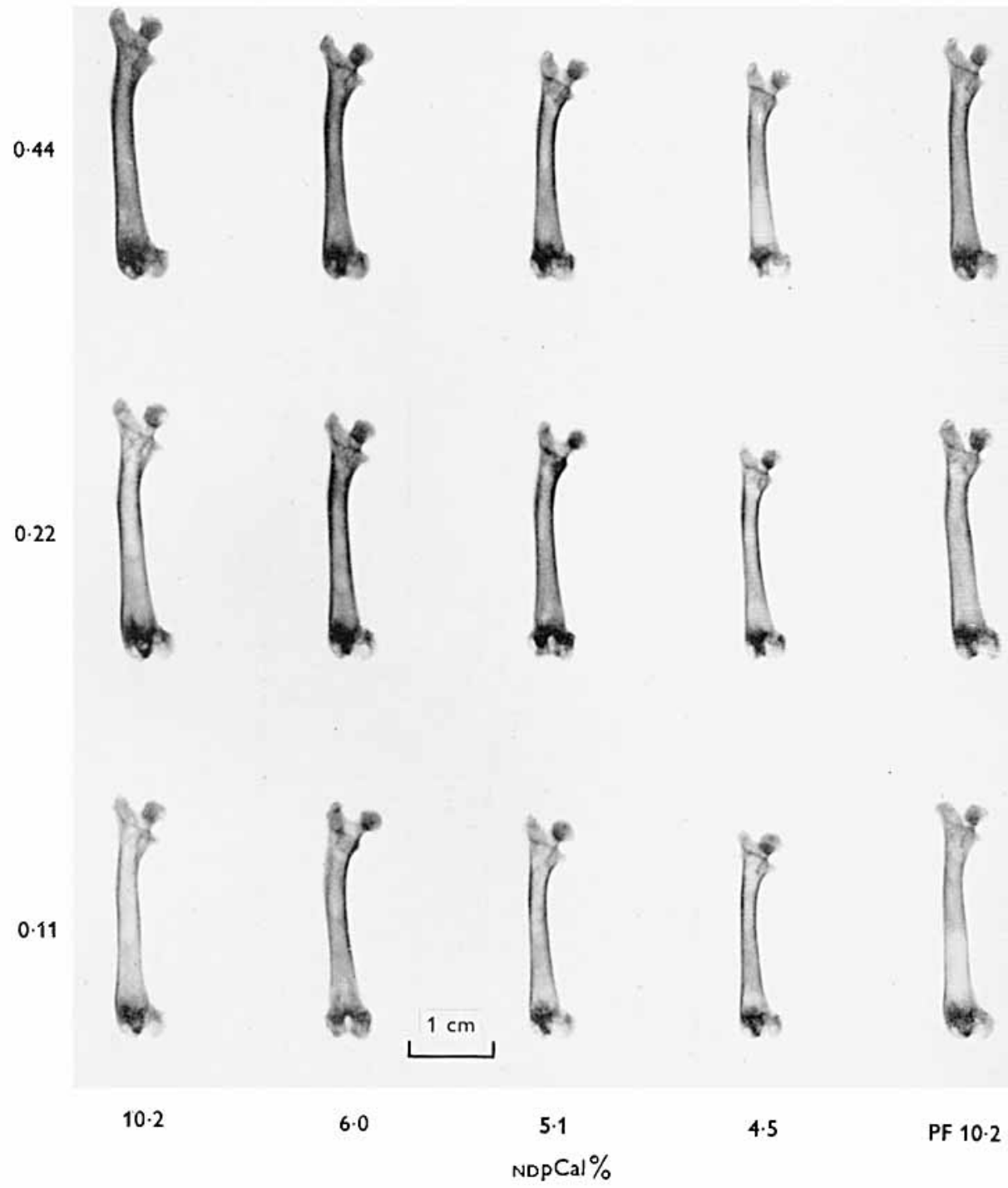

PF 10.2

N. R. H. EL-MARAGHI, B. S. PI.ATT AND R. J. C. STEWART 

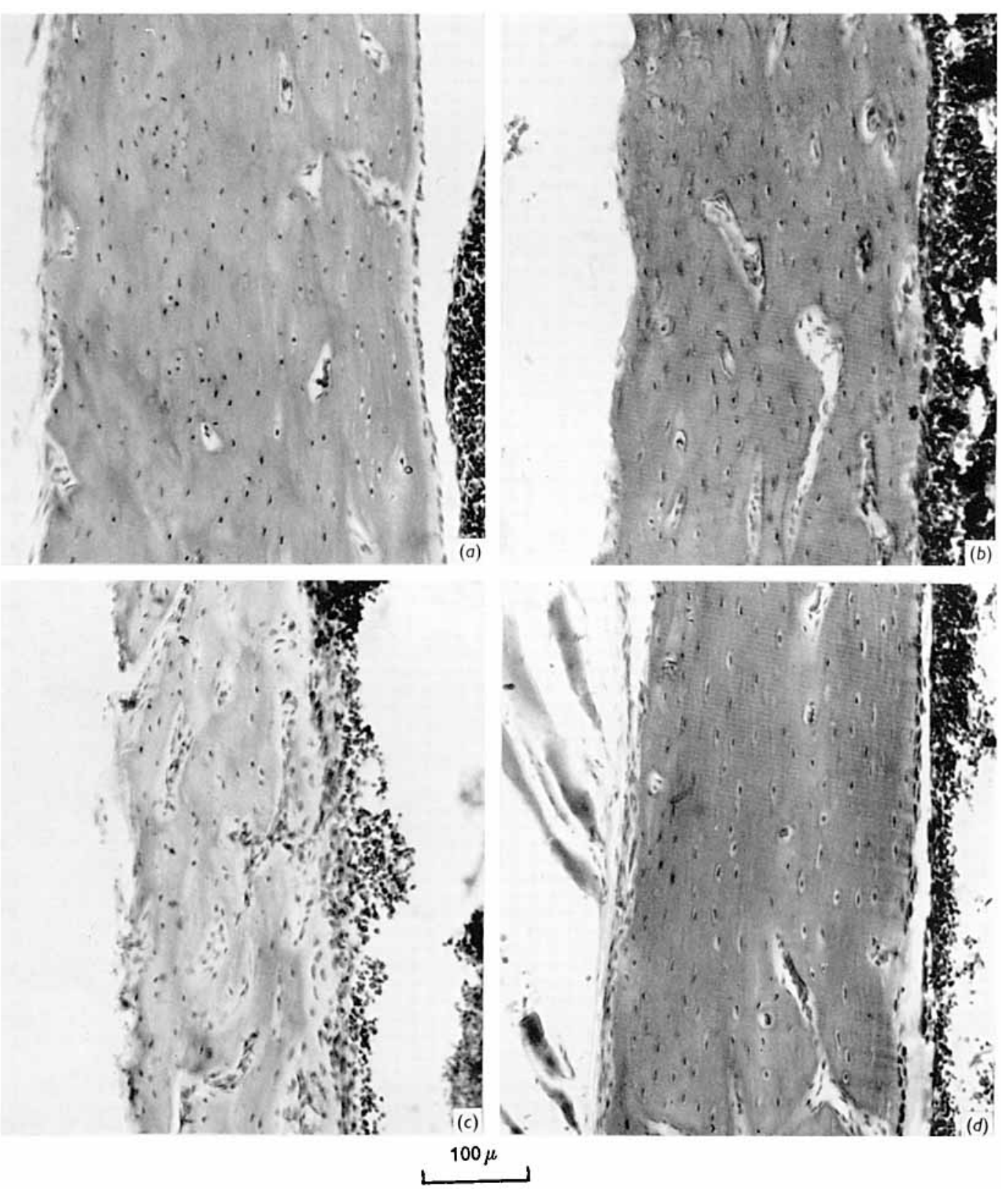

N. R. H. EL-MARAGHI, B. S. PLATT AND R. J. C. STEWART 

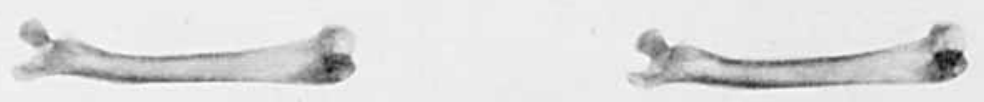

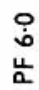

Ot
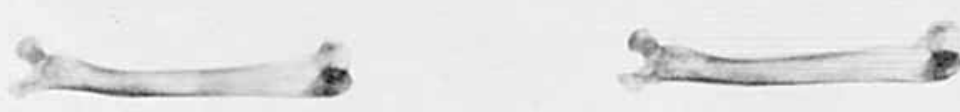

$\stackrel{+}{+}$
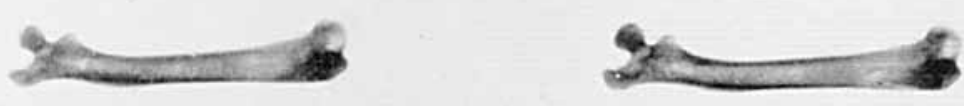

웅

E]
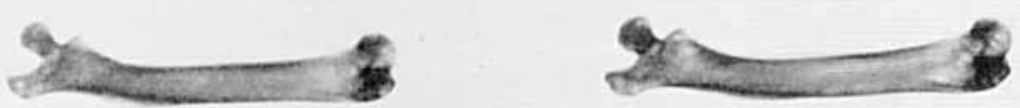

0
$\dot{b}$
ù

ro
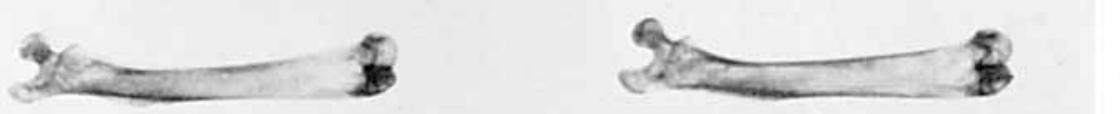

$\stackrel{\circ}{\circ}$
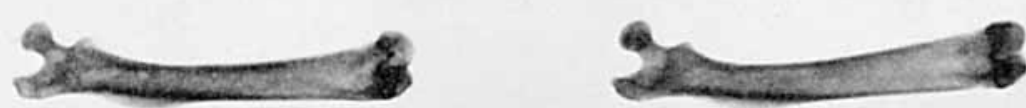

$\stackrel{\circ}{\dot{0}}$

导

$\bar{o}$

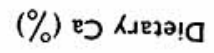



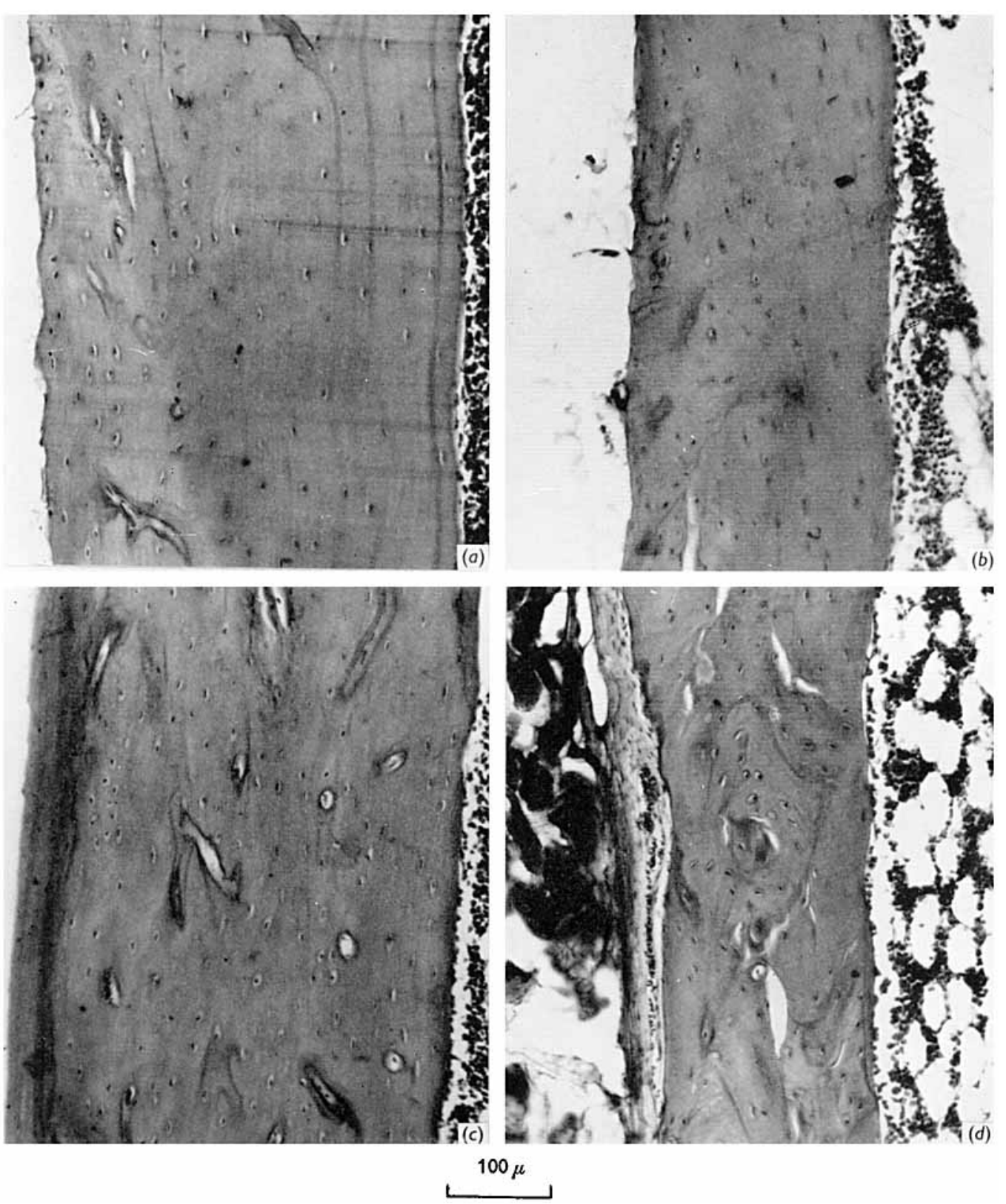

N. R. H. EL-MARAGHI, B. S, PLATT and R. J. C. STEWART 
British Fournal of Nutrition, Vol. I9, No. 4

Plate 5

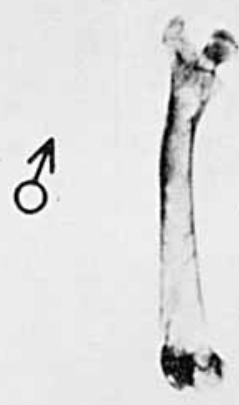

(1)

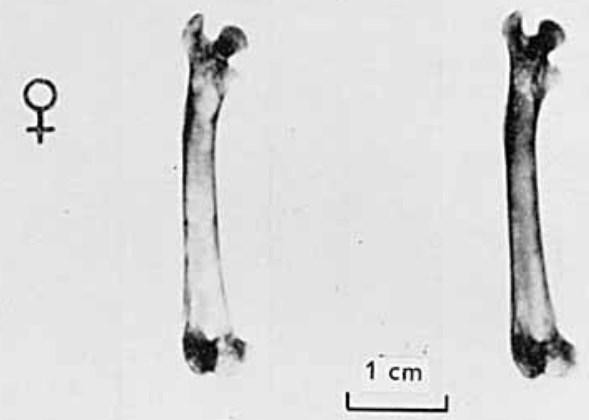

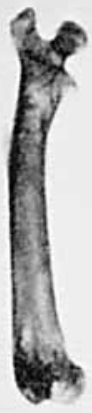

(3)

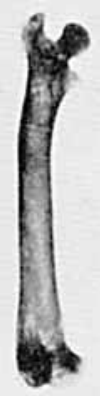

N. R. H. EL-MARAGHI, B. S. PLATT AND R. J. C. STEWAR'T 
British Fournal of Nutrition, Vol. 19, No. 4

Plate 6

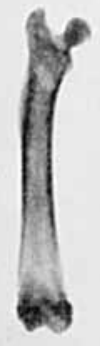

(1)

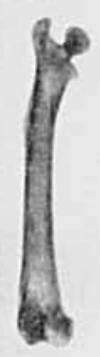

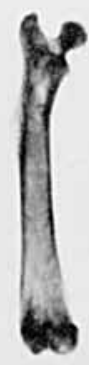

(2)

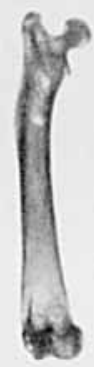

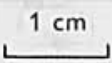

(3)

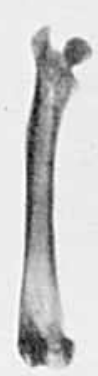

(a)

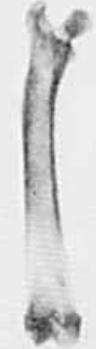

(4)

(b)

N. R, H, EL.-MARAGHI, B. S. PLA'TT AND R. J. C. STEWAR'T 
Pl. 5. Expt 2. Radiographs of the femurs of adult rats maintained from the 28 th to the 48 th week of age on a diet having a protein value of $\mathrm{NDpCal} \%=1.6$ and $0.1 \mathrm{I} \% \mathrm{Ca}$, and then for Io weeks on a diet of $\mathrm{NDpCal} \%=\mathrm{r} \cdot 6$ with $0.44 \% \mathrm{Ca}(\mathrm{I})$, NDpCal $\%=6.0$ without (2) and with (3) additional dietary Ca. Note increased density of the bones of animals given the diets of higher protein value.

P1. 6. Expt 3. Radiographs of the femurs of aged rats maintained on diets having different protein values and $\mathrm{Ca}$ concentrations: (1) $\mathrm{NDpCal}_{\%}=10.2, \mathrm{Ca}=0.44 \%$; (2) $\mathrm{NDpCa} \%=10.2, \mathrm{Ca}=0.11$; (3) $\mathrm{NDpCal} \%=\mathrm{r} \cdot 6, \mathrm{Ca}=0.44 \%$; (4) $\mathrm{NDpCal} \%=1 \cdot 6, \mathrm{Ca}=0.11 \%$. (a) rats killed after 12 weeks on the experimental diets; $(b)$ rats which, after 12 weeks on the experimental diets, were all given, for a further 7 weeks, a diet having a protein value of NDpCal $\%=10.2$ and a $\mathrm{Ca}$ concentration of $0.44 \%$. Note rarefaction in the bones of animals given the low-protein diets $(a)$ and the apparent recovery after a high-protein regimen $(b)$. 